Chirurgia (2021) 116: 583-590

No. 5, September - October

Copyright@ Celsius

http://dx.doi.org/10.21614/chirurgia.116.5.583

\title{
MRI-Pathology Agreement in Rectal Cancer: Real-World Data from a Prospective Rectal Cancer Registry
}

\author{
Giulio Mari ${ }^{*}$, Jacopo Crippa $^{2}$, Isacco Montroni ${ }^{3}$, Dario Maggioni ${ }^{1}$, Giacomo Calini ${ }^{4}$, Mauro Totis ${ }^{5}$, Nicolo Tamini ${ }^{5}$, \\ Massimo Oldani ${ }^{5}$, Eugenio Cocozza ${ }^{6}$, Mattia Berselli ${ }^{6}$, Giacomo Borroni ${ }^{6}$, C. Magistro ${ }^{7}$, Giovanni Ferrari ${ }^{7}$, \\ Pietro Achilli ${ }^{7}$, Roberto Petri ${ }^{8}$, Antonio Ziccarelli ${ }^{8}$, Sara Crestale ${ }^{8}$, Vincenzo Bagnardi ${ }^{9}$, Giulia Peveri ${ }^{9}$, \\ Matteo Origi' on behalf of AIMS Academy Clinical Research Network
}

${ }^{1}$ General Surgery Unit, Desio Hospital ASST Brianza, Italy

${ }^{2}$ Colorectal Surgery Unit, Humanitas Rozzano, Italy

${ }^{3}$ General Surgery Unit, Ospedale degli Infermi, Faenza, Italy

${ }^{4}$ Department of Surgery, Mayo Clinic, Rochester, MN, USA

${ }^{5}$ General Surgery Unit, San Gerardo Hospital, Monza, Italy

${ }^{6}$ General Surgery Unit, Varese Hospital, Italy

${ }^{7}$ General Surgery Unit, Niguarda Hospital, Italy

${ }^{8}$ General Surgery Unit, University Hospital, Udine, Italy

${ }^{9}$ Statistical Department, Bicocca University, Italy

${ }^{*}$ Corresponding author:

Mari Giulio, MD

General Surgery Unit

Desio Hospital ASST Brianza

Via Mazzini 1 Desio (Italy) 20843

tel 00390362383221

fax 00390326383801

E-mail: giul_mari@yahoo.it

Abbreviations:

nCRT: neo-adjuvant chemo-radiation

therapy;

ASA: American Society of Anesthesiology;

MRI: Magnetic Resonance Imaging;

pCR: pathologic complete response;

AIMS: Advanced International Mini-Invasive

Surgery;

ESMO: European Society for Medical

Oncology;

NCCN: National Comprehensive Cancer

Network.

Received: 22.03.2021

Accepted: 08.06.2021

\section{Rezumat}

Concordanța dintre IRM și examenul histopatologic în cancerul rectal: studiu prospectiv pe baza Registrului pentru Cancer Rectal

Introducere: Imagistica prin rezonanță magnetică (IRM) este utilizată în mod obişnuit în stadializarea preoperatorie a cancerului rectal. Concordanța stadializării IRM cu examenul histopatologic final, deşi îmbunătățită, nu a ajuns încă la perfecțiune. Scopul acestui studiu este de a analiza gradul de concordanță dintre IRM şi examenul histopatologic la pacienții operați de cancer de rect mediu/inferior.

Material şi Metodă: Au fost incluşi în studiu pacienții la care s-a practicat intervenția chirurgicală pentru cancer rectal cu sau fără chimio-radioterapiei neoadjuvante (nCRT). În perioada ianuarie 2019 - decembrie 2019, au fost analizați 140 de pacienți înscrişi în registrul de cancer rectal al AIMS Academy. Dintre aceştia, 62 pacienți au primit nCRT.

Rezultate: In general, concordanța dintre IRM şi examenul histopatologic în ceea ce priveşte stadiul $\mathrm{T}$ şi stadiul $\mathrm{N}$ a fost de $64,7 \%$, respectiv, 69,2\%. Concordanța dintre IRM şi examenul histopatologic în ceea ce priveşte stadiul $\mathrm{T}$ a fost de $62,7 \%$ pentru 
pacienții care nu au primit nCRT şi $67,4 \%$ pentru pacienții care au primit nCRT $(p=0,62)$. Concordanța asupra stadiului $\mathrm{N}$ a fost de $76,3 \%$ pentru pacienții care nu au primit nCRT şi $60,0 \%$ pentru pacientii care au primit $\mathrm{nCRT}(\mathrm{p}=0,075)$.

Concluzii: Datele din literatură arată că IRM-ul este încă departe de a se corela cu rezultatul histopatologic, ceea ce ridică întrebări cu privire la acuratețea procesului prin care sunt luate deciziile în mod curent în cadrul comisiilor oncologice.

Cuvinte cheie: rezonanță magnetică, cancer de rect, chimio-radioterapie neoadjuvantă

\begin{abstract}
Introduction: Magnetic Resonance Imaging (MRI) is routinely used in preoperative rectal cancer staging. The concordance of MRI staging with final pathologic exam, albeit improved, has not yet reached perfection. The aim of this study is to analyze the agreement between MRI and pathologic exam in patients operated on for mid-low rectal cancer.

Material and Method: Patients undergoing neoadjuvant chemoradiation therapy (nCRT) or upfront surgery were analyzed. Between January 2019 to December 2019, 140 patients enrolled in the AIMS Academy rectal cancer registry were analyzed. Sixty-two patients received nCRT and 78 underwent upfront surgery.

Results: Overall, the agreement between MRI and pathologic exam on $\mathrm{T}$ stage and $\mathrm{N}$ stage were $64.7 \%$ and $69.2 \%$, respectively. The agreement between MRI and pathologic exam on T stage was $62.7 \%$ for patients who did not receive nCRT and $67.4 \%$ for patients who received nCRT $(\mathrm{p}=0.62)$. The agreement on $\mathrm{N}$ stage was $76.3 \%$ for patients who did not receive nCRT and $60.0 \%$ for patients who received $\mathrm{nCRT}(\mathrm{p}=0.075)$.

Conclusions: Real-world data shows MRI is still far from being able to correlate with the pathology findings which raises questions about the accuracy of the real-life decision-making process during cancer boards.
\end{abstract}

Key words: Magnetic Resonance Imaging, rectal cancer, neoadjuvant chemoradiation therapy

\section{Background}

Diagnostic staging of mid-low rectal cancer has achieved high levels of accuracy in recent years (1). Magnetic resonance imaging (MRI) of the pelvis has especially gained a central role in rectal cancer staging (2). Its accuracy has been shown to be between $31 \%$ and $100 \%$ in reporting the $\mathrm{T}$ stage and between 39\% and $95 \%$ for nodal involvement (3). Scientific literature agrees in entrusting MRI with the ability to study the stage rectal cancer up to the point of planning surgical and chemoradiotherapeutic treatment based on the information obtained $(4,5)$. According to the European Society for Medical Oncology
(ESMO) clinical practice guidelines on rectal cancer, nCRT is recommended if the CRM is involved/threatened at MRI (6). The accuracy of MRI in rectal cancer has reached increasingly high levels, but this data is limited by the fact that the majority comes from patients enrolled in clinical trials $(7,8)$. Nevertheless, the reliability of MRI outside of these settings is still unclear (9). We are missing a part of the 'real world scenario', which is rarely included in studies on pelvic MRI and rectal cancer.

In particular, the concordance between MRI staging and the final pathologic exam lack precise and reliable data. In addition, the accuracy of MRI in describing rectal cancer 
after radiation therapy seems to decrease when inquired $(10,11)$.

This study aims to analyze the concordance of MRI data with the pathology report of patients undergoing surgery for rectal cancer in a large multicenter population and to compare this concordance between patients who received nCRT and patients who underwent upfront surgery.

\section{Materials and Method}

After approval by the local ethic committees, patients enrolled in the AIMS Academy rectal cancer registry who underwent preoperative MRI were analyzed. All patients enrolled in the registry sign a written informed consent for trial participation. The Advanced International Mini-Invasive Surgery (AIMS) academy clinical research network was conceived to create a rectal cancer registry to prospectively collect data of consecutive patients operated on for rectal cancer in high volume colorectal surgical units in Northern Italy. Each of the six enrolling centers follows similar guidelines for the preoperative, intraoperative, and postoperative management of patients. Inclusion criteria for enrollment were: 1) histologically proved adenocarcinoma of the rectum; 2) patient aged $>18$ years old; 3) indication for surgical resection with curative intent. Exclusion criteria were emergency surgery, palliative operation, metastatic disease at presentation, or inability to perform a MRI scan (13). To be included in the AIMS registry, each center must perform at least 30 rectal resections per year, must have dedicated radiologists for rectal MRI, and discuss every

Table 1. Pairings between MRI data and pathological examinations

\begin{tabular}{ll}
\hline MRI parameters & $\begin{array}{l}\text { Pathological examination } \\
\text { parameters }\end{array}$ \\
\hline Grade of tumor response & Dworak grade \\
\hline Involvement of the mesorectal fascia & $\begin{array}{l}\text { Involvement of the mesorectal } \\
\text { fascia }\end{array}$ \\
\hline Involvement of small extramural veins & Infiltration: venous \\
\hline $\mathrm{T}-\mathrm{MRI}$ & $\mathrm{T}$ - Histology \\
\hline $\mathrm{N}-\mathrm{MRI}$ & $\mathrm{N}$ - Histology \\
\hline Stage $-\mathrm{MRI}$ & Histology Stage \\
\hline
\end{tabular}

rectal cancer case within an ad hoc multidisciplinary cancer board.

The first aim of the study was to assess the concordance between MRI data and the pathology report. The second aim is to compare this concordance between patients who received a nCRT and patients who underwent upfront surgery. Matched MRI and microscopic pathological collected parameters are listed in Table 1.

Rectal cancer treatment was approached according to NCCN guidelines (13). Preoperative assessment consisted of colonoscopy, CT scan of chest, abdomen, and pelvis, endorectal ultrasound, and pelvic MRI. All patients performed MRI in the enrolling centers.

Indication for nCRT was given after a multidisciplinary board discussion at the local institutions according to the NCCN Guidelines, and it is not questioned in this study (14).

In patients who did not receive nCRT, preoperative MRI data were compared with the pathology report, while restaging MRI data were used in patients who received nCRT. MRI imaging was performed according to the indication provided by Institute of Cancer Research, Sutton, Surrey, UK (15). The pathologic classification was assessed according to AJCC TNM stage (8th edition) (16). A pathologic complete response (pCR) was defined as absence of adenocarcinoma cells in the surgical specimen (ypT0N0M0).

\section{Statistical Analysis}

Baseline patients' characteristics are presented stratified by neo-adjuvant therapy status. Counts and percentages were used to summarize categorical variables, medians, and ranges to summarize continuous variables. Comparisons between the two independent strata were made through either a Chi-squared test for proportions or a Wilcoxon test for medians.

For categorical variables, the agreement between MRI and pathologic examination was evaluated through the percentage of agreement, defined as the sum of all valid concordant observations divided by the sum of 
all valid observations. Differences between strata were evaluated by a Chi-square test. All the analyses were performed using SAS software, version 9.4 (SAS Institute, Cary, NC).

\section{Results}

Of the 143 patients included from the AIMS Academy rectal cancer registry between January $1^{\text {st }}$ and December $31^{\text {st }}, 2019$, three did not perform MRI due to claustrophobia and were excluded, sixty-two (44\%) patients underwent nCRT, and seventy-eight (56\%) underwent upfront surgery. Patients' characteristics are described in Table 2. There was no statistically significant difference between the two groups in sex, age, BMI, ASA score, and tumor stage. The upper rectal cancers rate was higher in the upfront surgery group since upper rectal tumors are excluded from nCRT. 5 patients had undergone prior rectal surgery for hemorrhoids which did not change the clinical treatment fro rectal cancer.

Overall, the agreement between MRI and pathologic exam on $\mathrm{T}$ stage and $\mathrm{N}$ stage were $64.7 \%(91 / 140)$ and $69.2 \%(97 / 140)$, respectively. In particular, the agreement rate between

Table 2. Patients characteristics

\begin{tabular}{llll}
\hline $\mathbf{N}^{\circ}$ & $\begin{array}{l}\text { Neo-adjuvant } \\
\text { yes }\end{array}$ & $\begin{array}{l}\text { Neo-adjuvant } \\
\text { no }\end{array}$ & p-value \\
\hline 140 & 62 & 78 & \\
\hline Male, N (\%) & $21(33.9)$ & $28(35.9)$ & 0.90 \\
\hline Female, N (\%) & $41(66.1)$ & $50(64.1)$ & \\
\hline Age, median (range) & $69.5(32-90)$ & $71(42-90)$ & 0.27 \\
\hline Missing, N (\%) & $0(0.0)$ & $0(0.0)$ & \\
\hline BMI, median (range) & 24.5 & 25.4 & 0.92 \\
\hline Missing, N (\%) & $(16.2-42.2)$ & $(16.4-56.7)$ & \\
\hline High rectal cancer, N (\%) & $5(8.1)$ & $8(10.3)$ & \\
\hline Medium rectal cancer, N (\%) & $7(11.3)$ & $31(39.7)$ & $<0.001$ \\
\hline Low rectal cancer, N (\%) & $34(54.9)$ & $28(35.9)$ & \\
\hline ASA I, N (\%) & $13(21.0)$ & $12(24.3)$ & \\
\hline ASA II, N (\%) & $37(59.7)$ & $40(51.3)$ & \\
\hline ASA III, N (\%) & $11(17.7)$ & $25(32.1)$ & \\
\hline ASA IV, N (\%) & $1(1.6)$ & $1(1.3)$ & \\
\hline Previous rectal surgery, N (\%) & $1(1.6)$ & $4(5.1)$ & 0.50 \\
\hline Stage 0, N (\%) & $6(9.7)$ & $1(1.3)$ & 0.02 \\
\hline Stage I, N (\%) & $15(24.2)$ & $33(42.3)$ & \\
\hline Stage II, N (\%) & $24(38.7)$ & $21(26.9)$ & \\
\hline Stage III, N (\%) & $17(27.4)$ & $23(29.5)$ & \\
\hline
\end{tabular}

MRI and pathologic exam were 62.7\% (37/59) for upfront surgery patients who did not receive nCRT and $67.4 \%$ (29/43) for patients who received $\mathrm{nCRT}$ ( $\mathrm{p}=0.62$ for $\mathrm{T}$ stage), and $76.3 \%(45 / 49)$ and $60.0 \%(27 / 45)(p=0.075)$ for $\mathrm{N}$ stage.

The T stage was understaged at MRI in the $23.7 \%(14 / 59)$ and overstaged in the $13.6 \%$ (8/59) of upfront surgery patients (no nCRT), while was understaged in the $9.3 \%(4 / 43)$ and overstaged in the $23.3 \%(10 / 43)$ of patients who receive nCRT.

The $\mathrm{N}$ stage was understaged at MRI in $10.2 \%(6 / 59)$ and overstaged in $13.6 \%$ (8/59) of upfront surgery patients (no nCRT), while was undestaged in $8.9 \%(4 / 45)$ and overstaged in $31.1 \%(14 / 45)$ of patients who received nCRT.

The concordance between MRI tumor regression grade and Dworak tumor regression grade after nCRT was $74.3 \%$ (26/35), with $17.1 \%$ (6/35) underestimate and $8.6 \%(3 / 35)$ overestimate rates at the MRI. MRI-pathology concordance about the small extramural veins involvement was $77.8 \%(35 / 45)$ in upfront surgery patients (no nCRT) with 15.6\% (7/45) underestimate and $6.7 \%(3 / 45)$ overestimate rates, and $59.1 \%(13 / 22)$ in patients who receive nCRT, with $36.3 \%$ (8/22) underestimate and $4.5 \%(1 / 22)$ overestimate rate $(\mathrm{p}=0.11)$.

There were no (0/35) MRI underestimation and $2.9 \%(1 / 35)$ overestimation of the free circumferential margin in upfront surgery patients (no nCRT), while there were no $(0 / 20)$ underestimation and 25\% (5/20) overestimation in patients who received nCRT. Results are reported in Table 3.

\section{Discussion}

The presented data show a concordance between MRI and pathologic exam lower than the one reported by clinical trials $(17,18)$. Displaying a gap between a clinical trial and "real world setting" despite, the enrolling centers are participating in a rectal cancer registry with established and controlled qualitative criteria. The low concordance rate between MRI and pathologic examination is a 
Table 3. Accuracy of MRI with respect to pathological examination

T Stage

\begin{tabular}{|c|c|c|c|c|c|c|c|c|c|c|}
\hline & & & & & & istolo & & & & Accuracy \\
\hline Ne0-adjuvant & & & Missing data & Tis-T1 & T2 & T3 & T4a & T4b & Total & $p=0.62$ \\
\hline No $(\mathrm{n}=78)$ & MRI & Missing data & 1 & 2 & 5 & 11 & 0 & 0 & 19 & $\begin{array}{c}37 / 59 \\
(62.7 \%)\end{array}$ \\
\hline & & T1 SM 1-2-3 & 0 & 7 & 1 & 1 & 0 & 0 & 9 & \\
\hline & & T2 & 0 & 1 & 16 & 9 & 0 & 0 & 26 & \\
\hline & & T3 a-b-c & 0 & 2 & 3 & 14 & 2 & 0 & 21 & \\
\hline & & $\mathrm{T} 4 \mathrm{a}$ & 0 & 0 & 0 & 2 & 0 & 1 & 3 & \\
\hline & & T4b & 0 & 0 & 0 & 0 & 0 & 0 & 0 & \\
\hline & & Total & 1 & 12 & 25 & 37 & 2 & 1 & 78 & \\
\hline Yes $(n=62)$ & MRI & Missing data & 1 & 5 & 4 & 7 & 0 & 0 & 17 & $\begin{array}{c}29 / 43 \\
(67.4 \%)\end{array}$ \\
\hline & & T1 SM 1-2-3 & 0 & 0 & 0 & 0 & 0 & 0 & 0 & \\
\hline & & T2 & 0 & 2 & 5 & 2 & 1 & 0 & 10 & \\
\hline & & T3 a-b-c & 2 & 1 & 5 & 22 & 1 & 0 & 31 & \\
\hline & & $\mathrm{T} 4 \mathrm{a}$ & 0 & 0 & 1 & 0 & 1 & 0 & 2 & \\
\hline & & T4b & 0 & 0 & 1 & 0 & 0 & 1 & 2 & \\
\hline & & Total & 3 & 8 & 16 & 31 & 3 & 1 & 62 & \\
\hline
\end{tabular}

No neoadjuvant: understaged 14/59 (23.7\%), overstaged 8/59 (13.6\%)

Neodjuvant: understaged $4 / 43(9.3 \%)$, overstaged $10 / 43(23.3 \%)$

\section{N stage}

\begin{tabular}{|c|c|c|c|c|c|c|c|}
\hline \multirow[b]{2}{*}{ Neo-adjuvant } & & & \multicolumn{4}{|c|}{ Histology } & \multirow{2}{*}{$\begin{array}{r}\text { Accuracy (\% } \\
p=0.075\end{array}$} \\
\hline & & & Missing data & No & N1-N2 & Total & \\
\hline \multirow[t]{4}{*}{ No $(n=78)$} & MRI & Missing data & 0 & 9 & 9 & 18 & $\begin{array}{c}45 / 59 \\
(76.3 \%)\end{array}$ \\
\hline & & NO & 1 & 36 & 6 & 43 & \\
\hline & & $\mathrm{N}+$ & 0 & 8 & 9 & 17 & \\
\hline & & Total & 1 & 53 & 24 & 78 & \\
\hline \multirow[t]{4}{*}{ Yes $(n=62)$} & MRI & Missing data & 0 & 13 & 2 & 15 & $\begin{array}{c}27 / 45 \\
(60.0 \%)\end{array}$ \\
\hline & & NO & 2 & 15 & 4 & 21 & \\
\hline & & $\mathrm{N}+$ & 0 & 14 & 12 & 26 & \\
\hline & & Total & 2 & 42 & 18 & 62 & \\
\hline
\end{tabular}

No neoadjuvant: understaged 6/59 (10.2\%), overstaged 8/59 (13.6\%)

Neodjuvant: understaged 4/45 (8.9\%), overstaged 14/45 (31.1\%)

\section{Stage}

\begin{tabular}{|c|c|c|c|c|c|c|c|c|}
\hline \multirow{2}{*}{ Neo-adjuvant } & & & \multirow[b]{2}{*}{ Missing data } & \multicolumn{3}{|c|}{ Histology } & \multicolumn{2}{|r|}{ Accuracy (\%) } \\
\hline & & & & Stage 1 & Stage 2 & Stage 3 & Total & $p=0.22$ \\
\hline \multirow[t]{5}{*}{ No $(\mathrm{n}=78)$} & MRI & Missing data & 1 & 6 & 4 & 9 & 20 & $\begin{array}{c}38 / 58 \\
(65.5 \%)\end{array}$ \\
\hline & & Stage 1 & 0 & 22 & 5 & 4 & 31 & \\
\hline & & Stage 2 & 0 & 1 & 7 & 2 & 10 & \\
\hline & & Stage 3 & 0 & 5 & 3 & 9 & 17 & \\
\hline & & Total & 1 & 34 & 19 & 24 & 78 & \\
\hline \multirow[t]{5}{*}{ Yes $(n=62)$} & MRI & Missing data & 0 & 9 & 5 & 3 & 17 & $\begin{array}{c}23 / 43 \\
(53.5 \%)\end{array}$ \\
\hline & & Stage 1 & 0 & 5 & 0 & 1 & 6 & \\
\hline & & Stage 2 & 2 & 3 & 6 & 2 & 13 & \\
\hline & & Stage 3 & 0 & 4 & 10 & 12 & 26 & \\
\hline & & Total & 2 & 21 & 21 & 18 & 62 & \\
\hline
\end{tabular}

No neoadjuvant: understaged 11/58 (19.0\%), overstaged 9/58 (15.5\%)

Neodjuvant: understaged 3/43 (7.0\%), overstaged 17 (39.5\%) 
Table 3 (continuation). Accuracy of MRI with respect to pathological examination Involvement of small extramural veins

\begin{tabular}{|c|c|c|c|c|c|c|c|c|}
\hline \multirow[b]{2}{*}{ Neo-adjuvant } & & & \multirow[b]{2}{*}{ Missing data } & \multicolumn{3}{|c|}{ Histology } & \multicolumn{2}{|r|}{ Accuracy (\%) } \\
\hline & & & & No & Yes & Not assessed & Total & $p=0.11$ \\
\hline \multirow[t]{5}{*}{ No $(n=78)$} & MRI & Missing data & 1 & 20 & 6 & 0 & 27 & $\begin{array}{c}35 / 45 \\
(77.8 \%)\end{array}$ \\
\hline & & No & 0 & 34 & 7 & 0 & 41 & \\
\hline & & Yes & 0 & 3 & 1 & 0 & 4 & \\
\hline & & Not assessed & 0 & 3 & 3 & 0 & 6 & \\
\hline & & Total & 1 & 60 & 17 & 0 & 78 & \\
\hline \multirow[t]{5}{*}{ Yes $(n=62)$} & MRI & Missing data & 1 & 16 & 6 & 1 & 24 & $\begin{array}{c}13 / 22 \\
(59.1 \%)\end{array}$ \\
\hline & & No & 2 & 11 & 8 & 2 & 23 & \\
\hline & & Yes & 0 & 1 & 2 & 0 & 3 & \\
\hline & & Not assessed & 0 & 8 & 1 & 3 & 12 & \\
\hline & & Total & 3 & 36 & 17 & 6 & 62 & \\
\hline
\end{tabular}

No neoadjuvant: undestimate of involvement $7 / 45$ (15.6\%), overestimate of involvment 3/45 (6.7\%)

Neodjuvant: undestimate of involvement $8 / 22(36.3 \%)$, overestimate of involvment 1/22 (4.5\%)

Response to neo-adjuvant CRT

\begin{tabular}{|c|c|c|c|c|c|c|c|c|}
\hline \multirow[b]{2}{*}{ Neo-adjuvant } & & & \multirow[b]{2}{*}{ Missing data } & \multirow[b]{2}{*}{$0-1-2$} & \multicolumn{2}{|c|}{ Histology } & \multirow{2}{*}{\multicolumn{2}{|c|}{$\begin{array}{c}\text { Accuracy (\%) } \\
26 / 35 \\
(74.3 \%)\end{array}$}} \\
\hline & & & & & 3 & 4 & & \\
\hline \multirow[t]{5}{*}{ Yes $(n=62)$} & MRI & Missing data & 8 & 11 & 1 & 2 & 22 & \\
\hline & & Incomplete & 4 & 21 & 3 & 2 & 30 & \\
\hline & & Near complete & 1 & 3 & 4 & 1 & 9 & \\
\hline & & Complete & 0 & 0 & 0 & 1 & 1 & \\
\hline & & Total & 13 & 35 & 8 & 6 & 62 & \\
\hline
\end{tabular}

Neodjuvant: undestimate of response 6/35 (17.1\%), overestimate of response $3 / 35(8.6 \%)$

Circumferencial margin

\begin{tabular}{|c|c|c|c|c|c|c|c|}
\hline \multirow[b]{2}{*}{ Neo-adjuvant } & & & \multirow[b]{2}{*}{ Missing data } & \multicolumn{3}{|c|}{ Histology } & \multirow{2}{*}{$\begin{array}{c}\text { Accuracy (\%) } \\
p=0.01\end{array}$} \\
\hline & & & & No infiltration & Infiltration & Total & \\
\hline \multirow[t]{4}{*}{ No $(n=78)$} & MRI & Missing data & 23 & 15 & 0 & 38 & $\begin{array}{c}34 / 35 \\
(97.1 \%)\end{array}$ \\
\hline & & No infiltration & 5 & 34 & 0 & 39 & \\
\hline & & Infiltration & 0 & 1 & 0 & $\overline{1}$ & \\
\hline & & Total & 28 & 50 & 0 & 78 & \\
\hline \multirow[t]{4}{*}{ Yes $(n=62)$} & MRI & Missing data & 26 & 10 & 0 & 36 & $\begin{array}{c}15 / 20 \\
(75.0 \%)\end{array}$ \\
\hline & & No infiltration & 4 & 15 & 0 & 19 & \\
\hline & & Infiltration & 2 & 5 & 0 & 7 & \\
\hline & & Total & 32 & 30 & 0 & 62 & \\
\hline
\end{tabular}

No neoadjuvant: undestimate of infiltration $0 / 35(0.0 \%)$, overestimate of infiltration 1/35 (2.9\%)

Neodjuvant: undestimate of infiltration $0 / 20(0.0 \%)$, overestimate of infiltration $5 / 20(25.0 \%)$

constant in all the parameters analyzed and raises serious interrogations regarding the value of MRI-based treatment decisions for patients with rectal cancer (19).

Our study reports an overall concordance of MRI preoperative findings and final pathology of $64.7 \%(66 / 102)$ for the $\mathrm{T}$ stage and $69.2 \%$ (72/104) for the N stage.
In 2017, Moreno et al. reported MRI to be $87 \%$ sensitive (95\% CI: $81 \%-92 \%)$ and $75 \%$ specific (95\% CI: 68\%-80\%) for T stage and $77 \%$ sensitive (95\% CI: $69 \%-84 \%$ ) and $71 \%$ specific (95\% CI: 59\%-81\%) for lymph node involvement. With a 1-mm threshold, MRI can reach a sensitivity of $76 \%$ and a specificity of $88 \%$ in detecting the involvement of the 
circumferential margin (20). Wei, Ming-Zhu et al. in a recent meta-analysis, reported MRI to have a global sensitivity of $81 \%(95 \%$ confidence interval (CI), 67\%-90\%), and a global specificity of $67 \%$ (95\% CI, $51 \%-80 \%)$ in re-assessing $\mathrm{T}$ sage. Regarding re-assessing the $\mathrm{N}$ stage, the global sensitivity reported was $77 \%$ (95\% CI, $65 \%-86 \%)$, and the global specificity was $77 \%(21)$. Our reported results do not compare favorably with the studies above, even if all participating centers have high-resolution MR scanners and a dedicated gastrointestinal MRI radiologist.

The agreement between MRI data and the final pathologic exam does not seem to significantly differ between patients receiving nCRT and patients undergoing upfront surgery for rectal cancer in our multicenter sample. Regarding the agreement in detecting lymphnodes metastasis, the concordance between the MRI and the pathology findings was better in the group of patients not receiving nCRT. This difference, although not significant, could be exacerbated by the increase in the enrolled cases. It is known in fact that MRI accuracy for irradiated tissues is more difficult and particularly affected by an alteration of the MRI signal. De Jong et al. concluded in a recent meta-analysis that MRI has a poor ability to truly exclude nodal involvement in case of negative test results in irradiated patients, adding that the false-negative rate is therefore too high to alter the operative approach (22). Low agreement level between the restaging MRI and pathologic exam regarding lymph node involvement should be taken into serious consideration given its importance in detecting possible complete response (23).

Analogous is the ability of MRI found to describe tumor involvement of extramural veins. Unfortunately, data on venous infiltration were not uniformly present in radiological reports. As stated by Chung et al., the MRI parameters might depend on the examiner, particularly in describing real-life data (24).

A recent study by Ang Z. et al. retrospectively compared MRI and pathologic data in 114 "real world" patients undergoing rectal surgery. The reported MRI accuracy was $56.6 \%$ for $\mathrm{T}$ stage and $55.8 \%$ for $\mathrm{N}$ stage (25). Prediction of extramural disease was reported as accurate in $51 \%$ of patients, while the negative circumferential resection margin was accurately predicted in $98.6 \%$ of patients. These results quite are in line with our finding, corroborating the hypothesis that the discrepancy in $\mathrm{T}$ and $\mathrm{N}$ staging between MRI and pathologic examination is an actual issue in real-world practice.

This study has several biases. The heterogeneity of the professional figures involved in radiological and pathologic reporting can certainly play a main role in determining the levels of accuracy here reported. Missing data is a clear source of concern, above all when data entry happened within a prospective registry. However, the problem of missing data must be emphasized. Speaking about real world data and making them public can help us to realize how much the multidisciplinary and multicentric treatment of rectal cancer requires precision and dedication that is certainly not yet achieved. Excluding patients with incomplete data entry will certainly provide a more homogeneous sample, but it would not describe a real-world practice nor the enormous amount of work that still needs to be done, even within a rectal cancer registry. Updating and improving network experiences through continuous auditing will surely improve the level of diagnostic accuracy.

Another bias of this study is not to report the temporal distance between the end of nCRT, the restaging MRI and surgery. A tailored study on the timing of MRI and its accuracy in restaging rectal cancer should be performed.

\section{Conclusion}

In conclusion, our real-world data shows that, despite the known potentials, MRI is still far from being able to properly correlate with the pathologic findings, which raises questions about the accuracy of the real-life decisionmaking process during cancer boards. 


\section{Author's Contributions}

Mari $G$ and Crippa J conceived the trial. Achilli $\mathrm{P}$ and Orig $\mathrm{M}$. wrote the manuscript. Montroni I, Calini G and Maggioni D. revised the paper. Totis M, Tamini N, Oldani M, Cocozza E, Berselli M, Borroni G, Magistro C., Ferrari G., Petri R, Ziccarelli A, Crestale S, did the data collection. Bagnardi V.and Peveri G. did the statistical analysis. All authors have read and agreed to the published version of the manuscript.

\section{Conflicts of Interest and Source of Funding}

All authors declare that they have nothing to disclose. No funding was received for this trial. Because of the nature of the data collected, requests to access the dataset from qualified researchers trained in human subject confidentiality protocols may be sent to the corresponding author.

\section{Ethics of Approval}

The trial was approved by the ethics committee of each hospital.

\section{Data are Available}

https://redcap.unibs.it/redcap_v10.8.5/index.p hp?pid=116.

\section{References}

1. Gürses B, Böge M, Altınmakas E, Balık E. Multiparametric MRI in rectal cancer. Diagn Interv Radiol. 2019;25(3):175-182.

2. Beets-Tan RGH, Lambregts DMJ, Maas M, Bipat S, Barbaro B, CurvoSemedo $\mathrm{L}$, et al. Magnetic resonance imaging for clinical management of rectal cancer: Updated recommendations from the 2016 European Society of Gastrointestinal and Abdominal Radiology (ESGAR) consensus meeting. Eur Radiol. 2018;28(4):1465-1475. Epub 2017 Oct 17.

3. Keane $\mathrm{C}$, Young M. Accuracy of magnetic resonance imaging for preoperative staging of rectal cancer. ANZ J Surg. 2014;84(10):758-62. Epub 2013 Oct 8.

4. Gollub MJ, Arya S, Beets-Tan RGh, de Prisco G, Gonen M, Jhaveri K, et al. Use of magnetic resonance imaging in rectal cancer patients: Society of Abdominal Radiology (SAR) rectal cancer disease-focused panel (DFP) recommendations 2017. Abdom Radiol (NY). 2018;43(11):2893-2902.

5. Ma $B, X u Q$, Song $Y$, Gao $P$, Wang $Z$. Current issues of preoperative radio(chemo)therapy and its future evolution in locally advanced rectal cancer. Future Oncol. 2017;13(27):2489-2501.

6. Glynne-Jones R, Wyrwicz L, Tiret E, Brown G, Rödel C, Cervantes A, et al. Rectal cancer: ESMO Clinical Practice Guidelines for diagnosis, treatment and follow-up. Ann Oncol. 2017;28(suppl_4):iv22-iv40.

7. Blazic IM, Campbell NM, Gollub MJ. MRI for evaluation of treatment response in rectal cancer. Br J Radiol. 2016:89(1064):20150964.

8 Patel UB, Blomqvist LK, Taylor F, George C, Guthrie A, Bees N, et al. MRI after treatment of locally advanced rectal cancer: how to report tumor response - the MERCURY experience. AJR Am J Roentgenol. 2012;199(4): W486-95.

9. Horvat N, Tavares Rocha CC, Oliveira BC, Petkovska I, Gollub MJ. MRI of rectal cancer: tumor staging, imaging techniques, and management. Radiographics. 2019;39(2):367-387.

10. Nahas SC, Rizkallah Nahas CS, Sparapan Marques CF, Ribeiro U Jr, Cutait Cotti G, Imperiale AR, et al. Pathologic Complete Response in Rectal Cancer: Can We Detect It? Lessons Learned From a Proposed Randomized Trial of Watch-and-Wait Treatment of Rectal Cancer. Dis Colon Rectum. 2016;59(4):255-63.

11. Faletti R, Gatti M, Arezzo A, Stola S, Benedini MC, Bergamasco L, et al. Preoperative staging of rectal cancer using magnetic resonance imaging: comparison with pathological staging. Minerva Chir. 2018;73(1):13-19. Epub 2017 May 11.

12. Zhan $S$, Wang $X$, Huang $X$, Zhu $H$. Magnetic resonance imaging in restaging rectal cancer after neoadjuvant chemoradiotherapy. Chemoradiotherapy. J BUON. 2015;20(1):62-7.

13. Mari GM, Achilli P, Maggioni D, Crippa J, Costanzi ATM, Scotti MA, et al. Creation of a Rectal Cancer Registry in Italy by the Advanced International Mini-Invasive Surgery (AIMS) Academy Clinical Research Network. F1000Res. 2019;8:1736. eCollection 2019.

14. NCCN guidelines version 4.2018: Colon Cancer. (C) National Comprehensive Cancer Network, Inc. All Rights Reserved.2014

15. White IM, Scurr E, Wetscherek A, Brown G, Sohaib A, Nill S, et al. Realizing the potential of magnetic resonance image guided radiotherapy in gynaecological and rectal cancer. Br J Radiol. 2019;92(1098):20180670.

16. http://cancerstaging.org/references - AJCC rectal cancer staging

17. Danihel L Jr, Danihel L Sr, Rajcok M, Mosna K, Belan V, Varga I, et al. Significance of MRI in rectal carcinoma therapy optimization - correlation of preoperative $\mathrm{T}$ - and $\mathrm{N}$-staging with definitive histopathological findings. Neoplasma. 2019;66(3):494-498.

18. Xie H, Zhou X, Zhuo Z, Che S, Xie L, Fu W. Effectiveness of MRI for the Assessment of Mesorectal Fascia Involvement in Patients With Rectal Cancer: A Systematic Review and Meta-Analysis. Dig Surg. 2014; 31(2):123-34.

19. Taylor FGM, Quirke P, Heald RJ, Moran BJ, Blomqvist L, Swift IR, et al. Preoperative magnetic resonance imaging assessment of circumferential resection margin predicts disease-free survival and local recurrence: 5-year follow-up results of the MERCURY study. J Clin Oncol. 2014;32(1):34-43. Epub 2013 Nov 25.

20. Moreno CC, Sullivan PS, Mittal PK. MRI Evaluation of Rectal Cancer: Staging and Restaging. Curr Probl Diagn Radiol.2017;46(3):234-241. Epub 2016 Nov 21.

21. Wei MZ, Zhao ZH, Wang JY. The diagnostic accuracy of magnetic resonance imaging in restaging of rectal cancer after preoperative chemoradiotherapy: a meta-analysis and systematic review. J Comput Assist Tomogr. 2020;44(1):102-110.

22. De Jong E A, Josianne C E M ten Berge, Roy S Dwarkasing, Anton P Rijkers, Casper $\mathrm{H} J$ van Eijck. The accuracy of MRI, endorectal ultrasonography, and computed tomography in predicting the response of locally advanced rectal cancer after preoperative therapy: a metaanalysis. Surgery. 2016; 159(3): 688-99. Epub 2015 Nov 24.

23. Aker M, Boone D, Chandramohan A, Sizer B, Motson R, Arulampalam T. Diagnostic accuracy of MRI in assessing tumor regression and identifying complete response in patients with locally advanced rectal cancer after neoadjuvant treatment. Abdom Radiol (NY). 2018;43(12):3213-3219.

24. Chung E, Kang D, Lee HS, Cho ES, Kim JH, Park EJ, Baik SH et al. Accuracy of pelvic MRI in measuring tumor height in rectal cancer patients with or without preoperative chemo-radiotherapy. Eur J Surg Oncol. 2019;45(3): 324-330. Epub 2018 Oct 9

25. Ang ZH, De Robles MS, Kang S, Winn R. Accuracy of pelvic magnetic resonance imaging in local staging for rectal cancer: a single local health district, real world experience. ANZ J Surg. 2021;91(1-2):111-116. Epub 2020 Dec 28 